\title{
Screw Cap Device
}

National Cancer Institute

\section{Source}

National Cancer Institute. Screw Cap Device. NCI Thesaurus. Code C149891.

Hollow cylindrical object with screw thread, meant to close a container. 